\title{
ANTARA ULAYAT ADAT DAN HUTAN NAGARI: SEBUAH KEBIJAKAN PERHUTANAN SOSIAL DI MINANGKABAU
}

\author{
Tresno $^{1}$, Rizka Fitri Ana ${ }^{2}$, Muki Wicaksono ${ }^{3}$, Auviar R. Wicaksanti $^{4}$, Riche Deswita $^{5}$

\begin{abstract}
This article is the result from our fieldwork to observed about the rule of regulation the social forestry in South Solok, West Sumatera. As this research uses etnoscience approach where the informant will be choosed by perposive sampling. Since the rule of LHK/83 is implemeted in South Solok that became strategic place of political ecology for advantaging the village forest in the Customary Land of the Alam Surambi Sungai Pagu. Based on the results, there are differences in customary communal tenure between the darek region whose control is held by penghulu andiko, while the rantau region whose control is given to rajo. $R$ ajo is the head of the tribe who is in 4 the customary land in Alam Surambi Sungai Pagu. In the Alam Surambi Sungai Pagu community, the forest processing is divided into three, namely; 1) ulayat suku is an unprocessed highland forest or rimbo gadang; 2 ) ulayat kaum or harato pusako tinggi, which is a land of ancestor from ninik nan salapan and ninik 60 kurang like rice fields or sawah and will be passed on daughters; 3) ulayat saparuik, also known as Harato Pusako Randah, is a family property from parents or property owned by their father and mother during marriage in the form of fields or rimbo randah. After the issuance of 5 decrees of The Village Forest in Alam Surambi Sungai Pagu, some of rimbo gadang began to be used as a Village Forest, moreover the use of the forest began to take into account the nagari government. Hence, the boundaries of 4 customary land begin to blur. In addition, the existence of Nagari Forest does not only provide the legality for the people of Alam Surambi Sungai Pagu, but also provides the benefits for outside communities, LPHN and mining companies.
\end{abstract}

Keywords: Social Forestry, Political Ecology, The Village Forest, The Customary Land

\section{A. PENDAHULUAN}

$\mathrm{P}$ ermasalahan hutan sudah menjadi permasalahan di Indonesia, semenjak masa penjajahan hingga masa sekarang penggunaan lahan untuk kesejahteraan rakyat masih menjadi ketidak

${ }^{1}$ Komunitas Konservasi Indonesia (KKI-Warsi), Jambi.

${ }^{2}$ Staff of Department of Anthropology, FISIP,

Universitas Airlangga, Surabaya.

${ }^{3}$ Epistema Institute Law and Environmental Justice, Jakarta.

${ }^{4}$ Reforma Agraria dan Perhutanan Sosial, Jakarta

${ }^{5}$ Graduate student of Department of Anthropology, FISIP, Univeristas Andalas, Padang

* Corresponding Author: widyahasan38@gmail.com merataan di negeri ini. Padahal hutan merupakan salah satu sumber daya alam yang yang memiliki potensi besar dalam mensejahterakan masyarakat. Menurut Suharjito (1998), kepemilikan sumberdaya alam hutan memiliki status public property. Sesuai dengan UUD 1945 bahwa bumi, air dan kekayaan yang terkandung didalamnya adalah rahmat Tuhan dan dikuasai oleh Negara untuk sebesar-besarnya kemakmuran rakyat. Menurut UU No. 41 Tahun 1999, salah satu penyelenggaraan kehutanan bertujuan sebesar-besarnya untuk kemakmuran rakyat yang berkeadilan dan berkelanjutan dengan mengoptimalkan 
aneka fungsi hutan meliputi fungsi konservasi, fungsi lindung, dan fungsi produksi untuk mencapai manfaat lingkungan, sosial, budaya, dan ekonomi, yang seimbang dan lestari. Sesuai dengan kebijakan Jokowi mengembangkan Indonesia dari pinggiran, yang mana pemerintah akan menjamin kepastian hukum hak kepemilikan tanah, penyelesaian sengketa tanah dan menentang kriminalisasi penuntutan kembali hak tanah masyarakat serta mendorong land reform dan program kepemilikan tanah seluas 9 juta hektar (dalam Yando ddk, 2018). Salah satu contoh kegiatan yang berbasis sistem Pengelolaan Hutan Berbasis Masyarakat (PHBM) atau yang lebih dikenal dengan perhutanan sosial. Perhutanan sosial merupakan wujud dari reforma agraria. Reformasi agraria atau pembaruan agraria adalah penataan ulang atau restrukturisasi pemilikan, penguasaan, dan penggunaan sumber-sumber agraria terutama tanah untuk kepentingan petani, buruh tani, dan rakyat kecil atau golongan ekonomi lemah pada umumnya. Inti dari pembaruan agraria adalah land reform yaitu redistribusi kepemilikan dan penguasaan tanah. Reforma agraria bidang kehutanan merupakan salah satu langkah penting dalam menyelesaikan konflik-konflik kehutanan. Perlu adanya kerjasama yang baik antara masyarakat, pemerintah dan LSM atatupun perusahaan dalam perhutanan sosial untuk perwujudan reforma agraria. Berdasarkan data dari Research Reforma Agraria sudah tercatat sampai periode november 2017 jumlah hutan yang telah disahkan dalam skema perhutanan sosial namun masih banyak hutan yang masih dalam tahap pengusulan sebagai skema perhutanan sosial yang mana dapat dilihat pada tabel dibawah ini;

Tabel 1. Jumlah Perhutanan Sosial di Indonesia tahun 2017

\begin{tabular}{|c|c|c|c|c|c|c|}
\hline \multirow[t]{2}{*}{ No } & \multirow[t]{2}{*}{ Skema } & \multirow{2}{*}{$\begin{array}{c}\text { Pra Kabinet } \\
\text { Kerja 2007- } \\
2014\end{array}$} & \multicolumn{4}{|c|}{ Kabinet Kerja } \\
\hline & & & 2015 & 2016 & 2017 & Total (Ha) \\
\hline 1 & HD & 2,00 & & $81.129,83$ & & \\
\hline 2 & $\mathrm{HKm}$ & 15 & & 2. & 10 & \\
\hline 3 & HTR & 198 & 2.8 & 14.13 & & 7,90 \\
\hline 4 & Kemitraan & $18.712,22$ & $16.300,99$ & 24. & 81 & \\
\hline 5 & Huta & 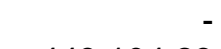 & & 13.121 & 1,25 & 33,24 \\
\hline & Jumla & $449.104,23$ & $103.648,47$ & 122.195.18 & $613.000,361$ & $1.301 .070,24$ \\
\hline
\end{tabular}

Sumber: Research Reforma Agaria dan Perhutanan Sosial

Semangat perhutanan sosial menurut Presiden Joko Widodo adalah memunculkan keadilan sosial bagi masyarakat yang hidup di daerah perhutanan sambil menjaga kelestarian sumber daya hutan. Semangat perhutanan sosial ini juga terwujud di Provinsi Sumatera Barat, salah satunya dukungan politis dari Gubernur Sumatera Barat Irwan Prayitno dengan menargetkan $500.000 \mathrm{Ha}$ lahan hutan menjadi bentuk perhutanan sosial (Hutan Nagari, Hutan Kemasyarakatan, Hutan Tanaman Rakyat, dan Hutan Adat). Selain itu, dukungan dari pemerintahan provinsi Sumatera Barat melalui Dinas Kehutanan Provinsi Sumatera Barat membentuk Kelompok Kerja (Pokja) Perhutanan Sosial dalam percepatan pengusulan. Ini semua tidak akan terwujud jika masyarakat di Sumatera Barat tidak antusias dalam semangat perhutanan sosial ini, dapat dibuktikan dengan lebih kurang $70.000 \mathrm{Ha}$ Hutan di Sumatera Barat sudah mendapatkan hak pengelolaan hutan dari Kementerian Lingkungan Hidup dan Kehutanan dan masih banyak lagi yang masih dalam proses pengusulan.

Masyarakat di Provinsi Sumatera Barat atau yang lebih dikenal Masyarakat Adat Minangkabau memiliki konsep atas tanah mereka dengan istilah tanah ulayat (lihat Benda-Beckman; Damsar, 2001; dan Erwin, 2012). Semenjak adanya beberapa perubahan skema hak pemanfaatan hutan di Indonesia. Telah beberapa peraturan yang dikeluarkan oleh pemerintah antara lainya program Perhutanan Sosial yang telah mengalami perubahan dari tahun ke tahun yang terakhir yaitu Permen LHK. No .83/2016. Dengan begitu melalui 192 | P a g e

DOI: 10.25077/jantro.v20.n2.p191-211.2018

JANTRO ISSN: 2355-5963 (Online)

under Lisensi Creative Commons Atribusi-BerbagiSerupa 4.0 Internasional 
kerjasama Pemerintah antara LSM KKI Warsi dalam wacana penguatan masyarakat sebagai pemilik hutan adat dengan beberapa skema Perhutanan Sosial. Skema perhutanan sosial ini pertama kali di sahkan di Kabupaten Solok tepatnya di Nagari Simanau, dikarenakan beberapa pertimbangan mengenai beberapa skema perhutanan sosial KKI-Warsi bersama masyarakat memutuskan untuk memilih salah satu skema yang cocok dalam penguasaan sistem ulayat adat dalam Nagari Simanau, sehingga diputuskan lahan seluas 1080 ha menjadi Hutan Nagari di Simanau. Secara bersamaan, pengajuan Hutan Nagari juga dilakukan di Nagari Alam Pauh Duo, tepatnya di Jorong Simancung, hutan seluas 650 ha dijadikan Hutan Nagari yang berstatuskan Hutan Lindung. Hal tersebut tidak memberhentikan pemerintah dan penggerak LSM yang berada di Kabupaten Solok Selatan untuk melindungi kawasan hutan yang masih belum terlindungi, yang pada masa itu dan sekarang menjadi target para $\mathrm{HPH}$, ilegal logging, ilegal mining dan masyarakat yang berladang. Semenjak hal itu sudah beberapa nagari di Kabupaten Solok Selatan yang sudah mendapatkan SK ataupun masih dalam proses pengusulan Hutan Nagari, setidaknya sudah 5 nagari yang telah mendapatkan SK secara resmi melalui bantuan KKI-Warsi yaitu Nagari Pakan Rabaa di Kecamatan Koto Parik Gadang Diateh, 3 Nagari di Kecamatan Sungai Pagu yaitu Nagari Pasir Talang Timur, Pulakek Koto Baru, Koto Baru, dan Jorong Simancung, Nagari Alam Pauh Duo di Kecamatan Pauh Duo.

Semenjak dengan berlakunya Hutan Nagari yang diperdakan negara, memang hutan yang berada pada kawasan masyarakat menjadi terlindung dan memberikan kesempatan kepada masyarakat untuk mengolah hutan mereka, dengan menguatkan wacana bahwa hutan tersebut milik masyarakat adat, tetapi masyarakat adat Minangkabau yang mana?. Pemangku kebijakan lupa akan mengenai kebijakan yang mereka keluarkan akan penentuan subyek dan objek hukum tentang penguasaan dan pengolahan hutan dalam masyarakat, sehingga itu menjadi tidak irelevan dikemudian hari dan akan menyebabkan konflik antar masyarakat. Setiap masyarakat di Indonesia memiliki sistem tenurial tentang penentuan subyek dan objek hukum mengenai hak kepemilikan dan pengolahan hutan seperti dalam suku Minangkabau ulayat adat merupakan milik kaum atau suku. Jika konsep ulayat adat Minangkabau digeneralisasikan seperti tanah adat yang berada di Jawa, sehingga itu berada unit sosial yang tidak relevan, lalu cara pemerintah menasionalisakan tentang konsep tanah adat dapat merubah sistem tenurial dan batas-batas ulayat secara adat, sedangkan masyarakat Minangkabau memiliki sistem tenurial tersendiri. Pada akhirnya yang awalanya hutan dicanangkan untuk seluruh masyarakat, nyatanya hutan hanya dijadikan sebagai kepentingankepentingan politik. Sehingga penelitan tentang Hutan Nagari pada masyarakat Minangkabau menjadi penting dipelajari, penelitian ini ditinjau dari sudut antropologis, untuk menjelaskan Hutan Nagari secara adat Minangkabau dan pengumpulan datadata etnografis guna menjelaskan sistem tenurial menurut masyarakat setempat dan perubahan tentang sistem tenurial pada masyarakat Minangkabau saat ini.

\section{B. METODE PENELITIAN}

$\mathrm{P}$ enelitian ini merupakan hasil penelitian lapangan peneliti di 5 Hutan Nagari, Kabupaten Solok Selatan tepatnya bekas Kerajaan Alam Surambi Sungai Pagu. yang secara administratif di Nagari Pakan Rabaa di Kecmatan Pekan Rabaa, Nagari Pasir Talang dan Nagari Koto Baru, Kecamatan Sungai Pagu dan Nagari Alam Pauh Duo di Kecamatan Pauh Duo. Metode yang digunakan peneliti menggunakan pendekatan etnoscience yang memandang bahwa pengetahuan masyarakat merupakan bagian penting dalam kehidupan suatu kelompok (Poerwanto, 2006), dengan demikian penelitian ini tidak saja menjelaskan bagaimana fenomena itu terjadi, tetapi yang terpenting mememahami apa yang dibalik fenomena 
tersebut, dan mempertanyakan mengapa fenomena tesebut terjadi (Arifin, dkk 2005, dimodifikasi Tresno, 2017:71).

\section{HASIL DAN PEMBAHASAN}

\section{Ulayat Adat Daerah Rantau}

ika beberapa penelitian telah menjelaskan daerah luhak nan tigo atau juga dikenal dengan dearah darek meliputi Luhak Tanah Data, Luhak Agam, Luhak Limo Puluh Koto. Ternyata terdapat perbedaan antara daerah darek dengan dearah rantau yang mana daearah rantau merupakan bekas penyebaran kekuasaan kerajaan Pagaruyung, sehingga banyak ditemukan daerah rantau memiliki raja-raja yang merupakan utusan Raja Pagaruyung untuk membukan ulayat baru seperti Pariaman, Pesisir Selatan, Solok Selatan, Pasaman dan daerah lainnya. Adapun dalam penelitian ini merupakan wilayah Kerajaan Alam Surambi Sungai Pagu yang berdiri pada abad ke 12 $-14 \mathrm{M}$. Terlihat jelas perbedaan pengusaan ulayat adat atau tanah komunal pada masyarakat Minangkabau terkhususnya pada masyarakat Alam Surambi Sungai Pagu. Jika daerah darek penguasaan ulayat adat itu dipegang oleh penghulu andiko. Namun berbeda dengan daearh rantau penguasaan ulayat adat itu diberikan kepada rajo. Rajo yang memimpin dalam pengolahan ulayat adat. Rajo lah sebagai kepala suku yang berada di 4 ulayat adat di Alam Surambi Sungai Pagu. Ulayat adat tersebut adalah milik 4 suku besar di Alam Surambi Sungai Pagu yaitu Suku Kampai dengan Rajo nya Tuanku Datuak Rajo Batuah yang memegang ulayat adat di Parik Gadang Diateh, Suku Panai, Suku Tigo Lareh dan Suku Melayu yang memegang ulayat adat Pasir Talang, dikarenakan pada masa itu terjadi perluasan daerah dan penyebaran penduduk pendatang sehingga ulayat tiga raja ini bertambah yaitu ulayat adat Koto Baru dan ulayat Pauh Duo. Seiring perjalanan banyak berumunculan mengenai pemberian nama 3 ulayat adat tersebut disebut ulayat Parik Gadang Dibawah milik rajo nan batigo (Panai, Tigo Lareh dan Melayu). Ulayat adat ini merupakan ulayat suku yang didalamnya berupa dataran rendah atau tanah data dan dataran tinggi atau rimbo yang akan dikelola secara bersama oleh ninik mamak. Adapun rajo sebagai penghulu suku, yang memiliki penguasaan untuk mengumpulkan pajak atau bungo yang berlaku ketika orang luar masuk ke Alam Surambi Sungai Pagu berupa nan bukik babungo kayu, nan lurah babungo ampiang, nan pasia babungo ameh (hutan/bukit berbunga kayu, lurah berbunga padi, pasir berbunnga emas), seluruh pajak digunakan untuk bersama.

Adapun rajo sebagai kepala suku yang mana dalam suku tersebut terdapat beberapa kaum pada awalnya merupakan ninik nan salapan dan ninik 60 kurang aso yang telah lama mengolah ulayat masingmasing. Kebanyakan ninik mamak di ke 4 suku ini lebih banyak mengolah dataran rendah daripada mengolah dataran tinggi berupa rimbo atau bukit. Daerah yang di tinggali oleh ninik mamak tersebutlah menjadi berupa luhak-luhak atau taratak yang kemudian membentuk sebuah kampuang-kampuang yang menandakan kaum mereka. luhak dan kampuang lah daerah administratif adat terendah pada masa itu. Terkadang pemberian nama taratak ataupun kampuang berdasarkan nama kaum tersebut. Sehingga ulayat suku sudah terbagi-bagi kedalam beberapa kaum yang telah memiliki ulayat kaumnya masingmasing dalam satu kampuang. Ketika suatu kaum yang telah mengolah ulayat suku yang belum diolah maka ulayat tersebut akan menjadi kaum tersebut, sehingga hampir jarang ditemukan lagi daratan rendah di Alam Surambi Sungai Pagu yang tidak berkepemilikan. rata-rata daratan rendah sudah menjadi sebuah pemukiman, sawah, parak, tabek yang sudah milik kaum. Berbeda dengan dataran tinggi pada masa itu, akses untuk mengolah daratan tinggi masih kurang intensif dalam pengolahan.

\section{Tata Guna Lahan}

$\mathrm{M}$ asyarakat Alam Surambi Sungai pagu memiliki pengetahuan lokal dalam pengolahan lahan yang sampai saat ini masih dipertahankan.

\section{4 | P a g e}

DOI: 10.25077/jantro.v20.n2.p191-211.2018

JANTRO ISSN: 2355-5963 (Online)

under Lisensi Creative Commons Atribusi-BerbagiSerupa 4.0 Internasional 
Mereka membedakan lahan berdasarkan daratan rendah berupa tanah data (tanah datar) dan daratan tinggi berupa rimbo (hutan) atau bukik (bukit) yang mana dari daratan tersebut mereka dapat mengolah lahan tersebut untuk memenuhi kebutuhan hidup mereka. Menurut mereka "sawah tatumpak tanah nan data, ladang tatumpak tanah nan lereang, nan bancah buek kak tabek, tobiang tanah golodo, hulu aia jadi rimbo (sawah ditanami tempat tanah yang datar, ladang ditanami tempat yang lereng bukit, dearah yang digenangi dengan air dibuat kolam ikan, tebing tanah yang rawan longsor, hulu air jadi hutan) .

Tabel 2. Kategori Penggunaan Lahan

\begin{tabular}{|c|c|c|c|}
\hline No & Jenis Lahan & Jenis Tanah & Jenis Tanaman \\
\hline 1 & 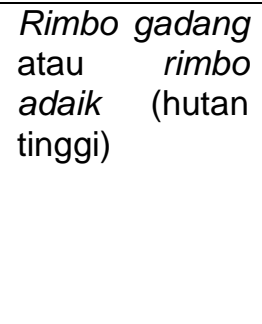 & $\begin{array}{l}\text { Di dataran tinggi atau tebing } \\
\text { bukit atau disebut masyarakat } \\
\text { tobing bukik dengan kemiringan } \\
\text { lebih dari } 45^{\circ}\end{array}$ & $\begin{array}{l}\text { Hutan yang belum dibuka } \\
\text { atau dikelola dengan } \\
\text { tanaman seperti maranti, } \\
\text { surian dan tanaman } \\
\text { diptrocupus dan dipercayai } \\
\text { tempat tinggal inyiak } \\
\text { (makhluk harimau yang } \\
\text { dianggap nenek moyang) }\end{array}$ \\
\hline 2 & Sawah & $\begin{array}{l}\text { Di tanah yang datar atau tanah } \\
\text { data yang mudah untuk } \\
\text { mendapat air atau dilewati } \\
\text { dengan batang aia (air sungai) }\end{array}$ & Padi \\
\hline 3 & Parak & $\begin{array}{l}\text { Di tanah yang datar yang kurang } \\
\text { mendapat air }\end{array}$ & $\begin{array}{lr}\text { Tanaman } & \text { mudo } \\
\text { Jangka pendek) } & \text { seperti } \\
\text { cabai, pisang, } & \text { kelapa, } \\
\text { kacang-kacangan, } & \text { dan } \\
\text { sayur-sayuran } & \end{array}$ \\
\hline 4 & $\begin{array}{l}\text { Ladang atau } \\
\text { Rimbo rendah } \\
\text { (hutan rendah) }\end{array}$ & $\begin{array}{l}\text { Di lereng bukit atau lereng bukik } \\
\text { dengan kemiringan kurang dari } \\
45^{\circ}\end{array}$ & $\begin{array}{l}\text { Tanaman tuo (Tanaman } \\
\text { jangka panjang) seperti kulit } \\
\text { manis }\end{array}$ \\
\hline
\end{tabular}

Sumber : Data Primer, 2018

Adapun beberapa penjelasan masyarakat mengenai pengkategorian pengolahan lahan sebagai berikut;

a. Rimbo gadang atau rimbo adaik atau sebutan lain hutan tinggi merupakan ulayat suku. Rimbo merupakan wilayah yang masih alami atau belum sama sekali diramba (dibuka) oleh masayarakat atau kaum tertentu. Biasanya rimbo ini masih dalam keadaan belukar dengan ditumbuhi pohon-pohon yang besar, tempat aliran batang aia, tempat tinggal nyiak mereka, dan berupa bukit-bukit (bukik).

"Ka rimbo, kayu tak buliah ditabang, rotan tak buliah dirungguik, manau tak buliah dipancang. Ka batang aia, aia tak buliah dikaruahi, batu tak buliah dibaliak, tobiang tak buliah diruntuah. Ka samak baluka, buah manih, buah masam tak buliah diambiak, dipanjek mudo jo lainlain. Kok pantang dilampaui, ka bawah indak baurek, ka ateh indak bapucuak, di tangah-tangah digiriak kumbang, hiduak sagan matipun tak namuah, bak karakok tumbuah dibatu (ke hutan, kayu tidak boleh ditebang, rotak tidak boleh diambil, manau tidak boleh dipotong. Ke sungai, air tidak boleh dikotori, batu tidak boleh dibalik, tebing tidak boleh diruntuhkan. Ke semak belukar, buah manis, buah masam tidak boleh diambil, dipanjat muda dan lainnya. Kalau pantangan 
dilanggar, ke bawah tidak berurat, ke atas tidak berpucuk, di tengah-tengah digirik kumbang, hidup segan matipun tidak mau)"

Di dalam rimbo inilah mereka memanfaatkan hasil hutan berupa kayu untuk dijadikan rumah, manau, madu. Akibat pengaruh perkembangan zaman rimbo menjadi salah satu cara penambah penghasilan bagi masyarakat untuk penjualan kayu dan menambang emas. Setiap masyarakat yang tinggal di alam surambi sungai pagu dapat mengolah rimbo gadang. Terkadang rimbo gadang juga disebut dengan hutan tinggi oleh beberapa masyarakat. Hutan tinggi ini memang sudah di lindungi sejak masa penjajahan Belanda, namun semenjak kepemipinan Soeharto masyarakat mulai banyak mengolah rimbo gadang sebagai ladang. Pada saat rimbo gadang telah diolah menjadi ladang, rimbo gadang tersebut akan berubah statusnya menjadi rimbo randah dan beralih kepemilikan yaitu milik pribadi. Ada beberapa daearah yang melindungi hutan mereka akibat beberapa alasan misalkan hutan tersebut merupakan cadangan air, memiliki banyak pohon, aliran sungai, ketinggiannya yang curam. Adapun ada beberapa jenis pohon yang berada di rimbo gadang seperti meranti, manau, rotan, paniangpaniang, katapiang, binuang, babayua, dan banio. Ada beberapa kayu yang diminati oleh illegal logging seperti kayu meranti dan banio.

Rimbo gadang ini biasanya akan diatur oleh rajo dan ninik mamak. Tiap-tiap kaum dalam suku boleh mengolah, sehingga ketika ada anak kemenakan dari kaum tertentu ingin mengolah maka penting orang tersebut untuk mendapat izin dari rajo dan kapalo kaum mereka. Seiring dengan adanya peraturan mengenai hutan nagari, beberapa rimbo gadang mulai dijadikan hutan nagari. Hanya saja ketika rimbo gadang sudah menjadi hutan nagari perizinan mengenai hutan tersebut akan bearalih ke pemerintahan nagari atau KAN. Hanya sebagian saja yang memintak izin kepada kepalo kaum. Dengan adanya hutan nagari maka status hutan tersebut dilindungi seperti Hutan Nagari Simancung berdasarkan prosedur hukum tidak boleh di olah. Sedangkan rimbo gadang biasanya hak kepemilikannya lepas saja, jika ada lahan bagus di hutan tersebut. Biasanya akan diramba oleh siapa saja. Rimbo gadang ini merupakan lahan yang kurang diolah secara intensif.

b) Sawah biasanya ditanami di daratan rendah atau tanah datar. Pembuatan sawah harus dilalui oleh batang aia dan laluan. Jika memang tidak ada batang aia, yang mana mereka cari tempat batang buatan, dengan mencari ketinggian dan dibawahnya dijadikan sawah seperti dibawah bukit, yang nantinya mereka akan buat banda (irigasi) yang bisa mengalir ke sawah mereka. Sebelum membuat sawah terkadang mereka buat tabek (kolam) terlebih dahulu barulah dijadikan sawah. Adapun dalam cara penanaman padi ini dilakukan sebanyak 3 kali, yang mana masyarakat di 5 nagari ini biasanya mereka tanam serentak dan panenpun biasanya dilakukan sebanyak 3 kali dalam 2 tahun. Sawah akan ditanam berdekatan dengan aliran sungai, sehingga mereka dapat membuat saluran irigasi untuk sawah nantinya ataupun celah-celah air dari bukit. Jika tidak ada aliran air, maka susah untuk dijadikan lahan sawah. Setelah panenpun mereka mepunyai tradisi turun basamo ka sawah mandarai kapalo banda (turun bersama ke sawah membantai kepala kerbau) dengan memotong kepala kerbau.

c) Parak merupakan tanaman pengganti padi atau tanaman yang ditanam tidak jauh dari rumah mereka. Ada beberapa sawah yang sudah dijadikan parak ataupun tanah datar yang tidak bias dijadikan sawah akan dibuat parak. Parak ini terkadang menggantikan sawah untuk beberapa waktu. Tujuanya untuk memperbaiki unsur tanah agar nantinya lebih subur. Adapun penyebutan parak ini dikarenakan dekat dengan rumah, sama halnya dengan ladang parak juga ditanam dengan sistem campur. Lahan yang digunakan juga tidak terlalu luas. Dalam parak biasanya berisikan berbagai

\section{6 | P a g e}

DOI: 10.25077/jantro.v20.n2.p191-211.2018

JANTRO ISSN: 2355-5963 (Online)

under Lisensi Creative Commons Atribusi-BerbagiSerupa 4.0 Internasional 
tanaman jangka pendek seperti sayursayuran, pohon jeruk, langkueh, sipadeh, kacang duduak, cabe, ubi, pisang, kelapa, pepaya, cimangkoh dan tanaman obat lainnya. Namun terkadang dalam parak juga terdapat tanaman jangka panjang, yang mana tanaman tersebut tidak cocok di tanam di ladang akibat banyaknya monyet di hutan. Sehingga tanaman jangka panjang di tanam di parak seperti coklat. Setelah panen tanaman mudo, barulah mereka ganti dengan sawah kembali.

d) Ladang merupakan kebun yang berada di lereng bukit bukan di tebing bukit. Sebelum membuat ladang, mereka perlu mancaliak tanah landai dan tanah tobing batinggaan (tanah tebing ditinggalkan). Tidak seperti sekarang sudah banyak masyarakat yang berladang di tebing bukit. Setelah itu barulah mereka akan meramba dan menebang tanaman kayu di sekitar lahan yang akan menjadi ladang mereka. Sebelum kayu itu ditebang mereka juga tidak menebang pohon di dekat sungai kira-kira $100 \mathrm{~m}$. Hal tersebut dilakukan agar sungai mereka tetap tidak kering, ladang mereka dekat dengan sungai, dan penahan agar tidak terjadi longsor. "dulu ulu anak aia ko ditinggaan, kini
ndak di tapi ulu anak aia ditanam juo,
kalau paneh ko jadinyo tanah
maranggang, kalau hujan masuak
tanah ko jadinyo lah lunak dan lah
lapuak ndak apo ureknyo lai, nan pohon
ko ado gunonyo untuak aia, apabilo
pohon ko jarang, batang aia ko jadinyo
ketek, jadilah inyo galodo (dulu ulu anak
air kami tinggalkan, sekarang tidak ulu
sungai juga ditanam, kalau musim
panas nanti tanahnya merenggang,
kalau musim hujan airnya masuk ke
tanah itu dan menjadi lunak dan
akhirnya rapuh tidak ada penahanya
lagi, pohon ini berguna untuk air,
apabila pohon ini sudah jarang, suangi
ini akan mengering, akhirnya jadilah
longsor)"
Mengenai kayu yang sudah ditebang tidak mereka bakar, hanya saja mereka akan membersihkan dahan-dahan kayu tersebut dimana daerah yang akan ditanam. Sehingga mereka tidak membakar kayu yang di tebang, karena menurut mereka jika sudah diramba, ditabang dan pohon tersebut tidak dibakar karena menghabiskan waktu. Lebih baik didiamkan saja dan pohon berguna untuk menutupi lahan agar lahan tersebut lama ditumbuhi semak-semak dan akibat pelapukan pohon berguna untuk pupuk alami.

"untuk pencarian lereng ada juga yang sampai ke atas, cuman dilihat kemiringanya kalau sudah tobing bana tidak bisa kita tanami. Selain tanah yang tebing (tobing), tidak boleh mereka tanam, ada beberapa pertimbangan lainnya yang menyebabkan mereka tidak boleh membuka ladang disana yang mana menebang pohon yang berdekatan dengan ulu batang aia (hulu sungai). Jika memang terjadi longsor menu- rut bapak $E$, itu penyebabnya bukan lagi hutanya tetapi manusianya".

Ladang ini biasanya berupa tanaman jangka panjang yang mereka kenal dengan tanaman tuo, ladang biasanya ditanam jauh dari rumah. Sehingga membutuhkan waktu untuk pergi ke ladang bahkan membutuhkan beberapa jam ke ladang milik masyarakat. Sifat ladang ini juga ditanam dengan sistem campur, yang mana dalam satu petak lahan atau satu hektar lahan ditanami dengan berbagai jenis tanaman jangka panjang misalkan mereka tanam karet bersebelahan dengan pohon kayu manis. Bahkan menurut Bapak E, kadang-kadang jika ada bibit durian atau mahoni (anak mahoni) mereka tanam juga disitu. Sebelum menunggu kopi besar, maka mereka juga tanam terkadang cabe rawit disebelah pohon kopi untuk selingannya. Untuk penggatian tanaman juga menurut Bapak Dtk K, tanaman jangka panjang ini tidak mesti diganti kecuali misalkan pohon durian atau kopi yang mati/tua baru bisa di ganti. Namun ada 
beberapa hal yang menyebakan masyarakat baik di 5 nagari ini mengganti tanaman mereka akibat pasar atau ikut-ikutan bedasarkan penjelasan bapak $\mathrm{M}$;

"kalau lagi musim karet baru urang tanam karet, kalau lai sadang musim kopi urang ganti tanaman karet wak dengan kopi, tapi kini wak nanam kopi se, kalau usahako punyo prinsiplah sabananyo jangan dicam- pua tanam ko labiah ancak dipisahan, istilahnyo di Miang takicuah ayam palala rumah maha kopi tanam kopi maha karet tanam karet, disaat ala ditanam bilo hasilnyo, harago kopi la nurun se dan ndak terencana (kalau lagi musim karet baru orang-orang tanam karet, kalau lagi sedang musim kopinya yang mahal baru ganti tanaman karet, tapi sekarang saya tanam dengan kopi, kalau usaha ini punya prinsiplah yang sebenarnya jangan dicampur tanamanya labih baik dipisahkan, istilahnya dalam minang takicuah ayam palala rumah, mahal kopi tanam kopi, mahal karet tanam karet)".

Ada beberapa jenis tanaman yang mereka tanam seperti durian, kopi, kayu manis, karet, petai, dan coklat. Namun ada beberapa tanaman yang tidak cocok ditanam di ladang mereka. Dikarenakan banyak monyet yang sering memakan hasil panen mereka seperti tanaman coklat, sehingga pohon coklat terkadang mereka tanam di parak dekat rumah mereka.

\section{Jenis-Jenis Hak Ulayat}

Tabel 2. Jenis-Jenis Hak Ulayat

\begin{tabular}{|c|c|c|c|c|c|c|}
\hline No & $\begin{array}{c}\text { Jenis } \\
\text { Ulayat/ } \\
\text { Wilayat }\end{array}$ & $\begin{array}{l}\text { Subjek } \\
\text { Hak }\end{array}$ & Jenis Hak & $\begin{array}{l}\text { Mekanisme } \\
\text { Penguasan }\end{array}$ & Obek Hak & Pengunaan \\
\hline 1 & $\begin{array}{l}\text { Ulayat } \\
\text { Suku }\end{array}$ & $\begin{array}{l}\text { Seluruh } \\
\text { masyara } \\
\text { kat } \\
\text { Alam } \\
\text { Surambi } \\
\text { Sungai } \\
\text { Pagu } \\
\text { yang } \\
\text { sesuku }\end{array}$ & $\begin{array}{l}\text { 1. Rajo hak } \\
\text { memimpin } \\
\text { wilayat dan } \\
\text { mengumpul- } \\
\text { kan upeti } \\
\text { untuk } \\
\text { pendatang } \\
\text { 2. Hak Milik } \\
\text { Sasuku } \\
\text { (Komunal) } \\
\text { 3. Anak } \\
\text { Kemenakan } \\
\text { Hak Mengelola }\end{array}$ & $\begin{array}{l}\text { Mengolah } \\
\text { Ulayat Suku } \\
\text { dengan } \\
\text { meminta } \\
\text { izin dengan } \\
\text { raja dan } \\
\text { ninik } \\
\text { mamak di } \\
\text { masing- } \\
\text { masing } \\
\text { ulayat adat }\end{array}$ & $\begin{array}{l}\text { Daratan rendah } \\
\text { yang belum } \\
\text { dihuni dan } \\
\text { daratan tinggi } \\
\text { yang belum } \\
\text { diolah berupa } \\
\text { rimbo (hutan) }\end{array}$ & $\begin{array}{l}\text { Dikelola oleh } \\
\text { Seluruh } \\
\text { Kemenakan } \\
\text { Niniak Mamak }\end{array}$ \\
\hline 2 & $\begin{array}{l}\text { Ulayat } \\
\text { Kaum }\end{array}$ & $\begin{array}{l}\text { Anak } \\
\text { Kemena } \\
\text { kan }\end{array}$ & $\begin{array}{l}\text { 1. Hak Milik } \\
\text { Kaum } \\
\text { 2. Anak } \\
\text { Kemenakan } \\
\text { Hak Mengelola }\end{array}$ & $\begin{array}{l}\text { Meminta } \\
\text { izin kepada } \\
\text { niniak } \\
\text { mamak }\end{array}$ & $\begin{array}{l}\text { Sawah dan } \\
\text { Parak }\end{array}$ & $\begin{array}{l}\text { Menjadi Jaminan } \\
\text { Sosial Anggota } \\
\text { Kaum }\end{array}$ \\
\hline 3 & $\begin{array}{l}\text { Ulayat } \\
\text { Sapa- } \\
\text { ruik }\end{array}$ & Pribadi & $\begin{array}{l}\text { Hak Milik } \\
\text { Pribadi }\end{array}$ & $\begin{array}{l}\text { Membeli, } \\
\text { upah buruh, } \\
\text { hasil } \\
\text { pembukaan } \\
\text { sendiri } \\
\text { (tabek } \\
\text { tabang) } \\
\text { atau } \\
\text { kelompok } \\
\text { koperasi, }\end{array}$ & $\begin{array}{l}\text { Ladang atau } \\
\text { rimbo randah } \\
\text { (hutan rendah) } \\
\text { dan Sawah }\end{array}$ & $\begin{array}{l}\text { Menjadi Jaminan } \\
\text { Sosial Anggota } \\
\text { Keluarga }\end{array}$ \\
\hline
\end{tabular}

Sumber : Data Primer, 2018

198 | P a g e

DOI: 10.25077/jantro.v20.n2.p191-211.2018

JANTRO ISSN: 2355-5963 (Online)

under Lisensi Creative Commons Atribusi-BerbagiSerupa 4.0 Internasional 
Menurut masyarakat ulayat atau sebutan lainnya wilayat merupakan seluruh wilayah penguasaaan dan pemanfaatan sumber daya alam di Alam Surambi Sungai Pagu baik itu berupa tanah, sungai, dan hutan. Didalam ulayat inilah diatur hak kepemilikan dan hak penguasaan wilayah teritorial termasuk tanah, hutan dan sawah yang dimiliki pada suku di Alam Surambi Sungai Pagu. Maka dari itu peneliti akan menjelaskan secara mendetail tentang ulayat suku, ulayat kaum dan ulayat saparuik yang akan dijelaskan sebagai berikut;

\section{a. Ulayat Suku}

Sebagaimana yang telah dijelaskan sebelumnya, ulayat suku merupakan ulayat dari 4 suku di Alam Surambi Sungai Pagu yang mana setiap suku di pimpin oleh rajo. Rajo berfungsi sebagai pengatur dan mengawasi jika terdapat orang luar yang akan mengolah ulayat suku. Sebenarnya ulayat suku ini berupa daratan rendah dan daratan tinggi yang belum diolah sama sekali. Ulayat suku ini terbagai menjadi 4 bagian yaitu ulayat Parik Gadang Diateh merupakan ulayat milik suku Kampai, ulayat Pasir Talang merupakan miliki ulayat suku Panai, suku Tigo Lareh dan suku Melayu, sedangkan ulayat Koto Baru dan ulayat Pauh Duo merupakan ulayat hasil penyebaran penduduk di Pasir Talang dan pendatang namun secara kepemilikan milik suku Panai, suku Tigo Lareh dan suku Melayu. Namun nyatanya ulayat suku pada bagian rendah sudah diolah oleh ninik mamak dulunya. Sehingga masing-masing suku terdiri dari beberapa kaum, maka pada masa itu niniak mamak baik niniak mamak nan salapan maupun niniak mamak 60 kurang aso telah lama mencancang malatiah di wilayah Alam Surambi Sungai Pagu, sehingga dataran rendah sudah terbagi-bagi kedalam beberapa ulayat kaum. Sebagaiman sudah dijelaskan beberapa informan mengenai ulayat suku ini sudah terbagi bagi hak alah samo-samo punyo, rimbo bamintalah, ukuran tabe bepedalak, ala buntel lah bamintalak yang berarti setiap suku dalam kaum sudah ada hak nya masing-masing, rimbo memintak izin, ukuran kolam sudah ditentukan, sawah yang sudah diberi batas, dan kaum sudah ada diberi hak-haknya masing-masing yang diberikan oleh ninik mamak mereka.

Sedangkan daratan tinggi berupa rimbo atau bukik tidak diolah secara intensif hanya berupa hutan lepas yang perlu meminta izin dalam pengolahanya, sehingga jarang sekali ditemukan rimbo kepemilikan kaum. Ada beberapa pengclaiman rimbo berupa ulayat kaum dengan istilah uyalat tunjuak atau penunjukan bukit sebagai ulayat mereka. Nyatanya ulayat tersebut masihlah merupakan ulayat suku. Hanya saja dapat ditemukan rimbo yang sudah kepemilikan pribadi yang nantinya akan dijelaskan pada ulayat saparuik.

\section{b. Ulayat Kaum}

Ulayat kaum disini merupakan warisan dari nenek moyang mereka dari generasi ke generasi yang sudah dibuka oleh niniak nan salapan dan niniak 60 kurang aso. Dulunya daratan rendah diolah secara intensif oleh ninik mamak Alam Surambi Sungai Pagu. Ulayat kaum ini biasanya di jadikan sebagai tempat tinggal atau rumah gadang, sawah dan parak. Sawah dan parak akan diberikan kepada anak perempuan, biasanya setiap anak perempuan akan diberikan sawah sebanyak sapiriang. Ulayat kaum merupakan harato pusako tinggi dalam kaum sehingga penggunaannya harus atas persetujuan seluruh anggota kaum. Jadi tanah kaum ini berupa tanah yang status kepemilikannya, dimiliki oleh kaum atau suku tertentu dalam kelompok masyarakat. Misalnya tanah milik kaum suku kampai, suku panai, suku sikumbang dan suku melayu. Keempat suku tersebut memiliki tanah kaumnya masing-masing dan batasbatas tertentu dengan pengolahanya akan diolah oleh kemenekan mereka. sebenarnya hak kepemilikan dan hak mengusahakan dimiliki oleh seluruh anggota suku atau kaum. Tanah ini nantinya akan diatur oleh penghulu atau niniak mamak pada kaum tersebut. Tanah jenis ini tidak dapat dijual dengan alasan penguasaanya milik bersama (komunal) yang gunanya untuk menjamin kehidupan suku mereka. 


\section{c. Ulayat Saparuik}

Ulayat saparuik juga dikenal dnegan harato pusako randah merupakan harta pencarian dari orang tua atau harta induaknya yang dimiliki oleh ayah dan ibunya semasa perkawinan. Harta ini juga dikenal dengan ulayat saparuik. Pusako rendah bisa berupa barang, hewan, tanah, rumah, tabek (kolam ikan), ladang dan sawah sapiriang. Apabila kedua orang tua meninggal maka akan diwariskan kepada anak-anaknya. Selain itu juga didalam harato pusako randah juga terdapat harta tembilang ameh yang merupakan hasil dari pembelian orang tuanya baik berupa sawah dan ladang. Adapun harato pusako randah diperbolehkan untuk dijual oleh anakanaknya dengan syarat "hiduak lah bapadok-padok, gagam marunduakrunduak (hidup sudah sengsara), namun mereka perlu meminta izin dengan mamak mereka. Maka dari itu ada beberapa keluarga yang memiliki sawah dan ladang milik pribadi bukan milik kaum. Dikarenakan orangtuanya mendapatkanya dari hasil jual beli (silih rugi tanah).

"Menurut Bapak Dtk Rj Bintang dan Bapak M, kalau harato saparuik ini sebenarnya milik perempuan (padusi). Namun sepanjangan zaman sudah ada anak laki-laki juga berhak mendapatkan kadang berdasarkan kesepakatan, saya lebih mengikuti cara Islam. Tanah saparuik ini isinyo ado tanah sawah, tanah kariang yang tanamanyo durian, maggis, ado juo tabek (tanah saparuik ini isinya ada tanah, sawah, tanah kering yang tanamanya durian, manggis dan ada juga kolam)"

Hutan akan berubah statusnya jika hutan tersebut sudah milik perorangan inilah yang disebut dengan ulayat saparuik. Sehingga ulayat suku mulai di klaim menjadi ulayat saprauik atau milik perorangan, maka dari itu status rimbo tinggi akan berubah menjadi rimbo randah yang mana lahan tersebut sudah di buka dengan ladang. Pengistilahan rimbo randah juga merupakan tempat tabek tabang yang berarti tebang sendiri-sendiri atau hak kepemilikan sendiri. Biasanya rimbo randah berada di lereng bukit yang sudah dijadikan ladang milik perorangan. Menurut Bapak Dtk Lelo di Rajo hutan ulayat suku bisa menjadi ulayat saparuik;

"....ulayat suku bisa menjadi ulayat saparuik sasuai dengan aturan, tentu ado negosiasi antaro niniak mamak dan kesepakatan, misalkan hutan ko ado kami ka bukak paladangan disitu kemenakan den mintak izin nio buka ladang disinan, dulu kan ba ulayatulayat Rajo, Rajo barat yang iko, yang timur Rajo iko, kini ko zaman lah maju kalau lah rancak ndak paralu malapor langsung ramba se, kalau niniak mamak ndak muah malarang beko ndak ado perkembangan kemenakan (hutan ulayat bisa menjadi hutan saparuik sesuai dengan aturan, tentu ada negoisasi antar niniak mamak dan kesepakatan, misalkan hutan ini ada kami berencana mau buka ladang disini, kemenakan saya mintak izin, dulu kan ini berulayat-ulayat, ulayat barat yang raja ini, yang timur raja ini, sekarangkan sudah zaman maju, kalau sudah bagus ngak perlu melapor langsung bersihin aja, tapi niniak mamak tidak enak melarang, nanti tidak ada perkembangan bagi kemenakan)".

Kenyataanya, rimbo randah akhirnya bisa dijual oleh niniak mamak dulunya dikarenakan hutan tersebut merupakan sudah ada hasil garapan pribadi. Sesuai dengan pepatah patitih Minangkabau "nan dulu nan mandapek nan kamudian manjalanan (sudah habis hartanya dijual oleh ninik mamak dahulu, tinggal cerita saja yang kita dengarkan). Hal inilah yang membedakan antara ladang dengan parak, jika parak berdekatan dengan rumah dan di tanah yang datar, sedangka ladang jauh dari rumah. Adapun dalam pembukaan ladang pada masyarakat Alam Surambi Sungai Pagu, mereka akan melakukan terelebih dahulu mancancang malatiah yaitu

\section{$200 \mid \mathrm{P}$ a g e}

DOI: 10.25077/jantro.v20.n2.p191-211.2018

JANTRO ISSN: 2355-5963 (Online)

under Lisensi Creative Commons Atribusi-BerbagiSerupa 4.0 Internasional 
mencari rimbo atau bukik yang belum ada pemiliknya. Setelah mereka mendapatkanya, maka mereka akan terlebih dahulu meminta izin ke ninik mamak mereka untuk mengolah lahan tersebut.

\section{Skema Perubahan Hak Ulayat}

Ada beberapa hal yang menyebabkan perubahan 4 ulayat suku di Alam Surambi Sungai Pagu. Nyatanya dataran rendah merupakan lahan yang secara intensif dikelola oleh nenek moyang di ulayat adat, sedangkan hutan merupakan daerah yang kurang diolah secara intensif pada masa itu. Dengan adanya beberapa perubahan yang terjadi di 4 ulayat adat ini baik semenjak berubahnya peraturan tentang pengolahan hutan, pengenalan komoditi pasar, perluasan daerah atau pembukaan daerah administratif baru dan datangnya pendatang di beberapa daerah baik di Nagari Pakan Rabaa, Nagari Pasir Talang Timur, Nagari Koto Baru, Nagari Pulakek Koto Baru dan Nagari Alam Pauh Duo. Ada beberapa hal yang menyebabkan penguasaan ulayat suku menjadi ulayat kaum baru, pribadi dan dimiliki oleh orang luar. Sehingga seseorang dapat melakukan pengusahaan lahan di wilayah ke-5 Nagari atau di daerah ulayat suku. Ada beberapa hal yang menyebabkan orang luar yang mengolah ulayat suku antara lain;

a. Perjanjian antara Rajo Bagindo di Balun dengan orang pendatang dengan sistem bagi hasil kepada raja atau pemberian upeti, perjanjian ini dilakukan antara orang luar yaitu orang Solok yang datang untuk membuat kebun dan mengolah sawah di ulayat suku Kampai di wilayat adat Koto Parik Gadang Diateh.

b. Sumando manyumando atau perkawinan, jika melalui perkawinan suku lain dapat memanfaatkan ulayat milik kaum istrinya, dikarenakan suaminya akan menjadi urang sumando dan sekalian ande bapak yang akan mengolah tanah kaum milik istrinya. Status pernikahan merupakan aspek yang berpengaruh terhadap pengusahaan hak kepemilikan lahan.
Jika tidak memiliki suku yang sama dengan suku yang berkuasa di suatu wilayah, maka seseorang harus menikah dengan salah satu anggota kaum dari suku Suku Kampai, Tigo Lareh, Panai dan Melayu. Hal ini dilakukan karena ninik mamak sebagai pihak yang berkuasa merasa memiiki lahan sehingga kegiatan apapun yang dilakukan pada lahan tersebut harus menghasilkan keuntungan bagi kaumnya terutama kemenakan perempuan. Hal ini dilakukan karena masyarakat menganut sistem kekerabatan matrilineal sehingga anak dari saudara perempuan adalah yang akan meneruskan generasi kaum. Jika melalui perkawinan suku lain dapat memanfaatkan ulayat milik kaum istrinya, dikarenakan otomatis suaminya sebagai urang sumando dan sekalian ande bapak dia yang akan mengolah tanah kaum milik istrinya seperti yang diungkapkan Bapak M;

“....cuman awalnyo yang ka ampek ko yang punyo ulayat kampai, panai, melayu, sikumbang misalnyo ka arah timur panai, untuk kelanjutan itu cuman mengetahui se nyo ulayat mereka, kalau ado urang sikumbang yang bukan ulayat kaum inyo ndak jadi masalah, dek karena awalnyo urangko sumando manyumando, awak misal suku panai menikah samo urang melayu dan wak olah atau wak baok ka panai baa cara memperdebatkanyo, yang mangolah kemenakan-kemenakan awak juo. Yang penting awak mengolah itu mintak izin samo niniak mamak awak (cuman awalnya yang ke empat suku tadi yang punya panai, melayu, sikumbang, kampai misalnya yang ke arah timur panai, untuk kelanjutanya itu cuman sekedar mengetahui saja ulayat mereka, kalau ada orang sikumbang yang mengolah di bukat ulayat mereka tidak masalah, karena awalnya juga orang ini mengikat suku mereka dengan hubungan perkawinan, seperti saya dari suku 
panai yang menikah dengan suku melayu dan saya bisa mengolah ulayat kaum istri saya atau saya bawak ke panai gimana cara memperdebatkanya yang mengolah kemenakan-kemenakan kami juga. Yang penting mengolah itu ada izin dari ninik mamak)".

\section{"kadang-kadang mamak ko dibaoknyo tanah kaum di rumah istrinyo, dijualnyo tu tentu ndak ado lai harato kemenekan, iko lah yang mbuek perselisihan (terkadang saudara laki-laki ini dibawaknya tanah milik kaum di rumah isrinya, dijualnya harta tersebut, pasti tidak ada lagi harta miliki kemenakan, ini yang bisa membuat perselisihan)"}

c. Tanah tagadai, walapun sejatinya tanah kaum tidak diperbolehkan untuk dijual namun tanah kaum dapat digadaikan dengan beberapa alasan menurut "rumah gadang katirisan" (rumah gadang sudah rusak (lapuak), tentu mereka bilang sama mamak mereka untuk diperbaiki, tetapi tidak ada uang akhirnya karena malu bisa menyalang/meminjam uang), "mayiak tabujuar" (tidak terselamat mayatnya, yang berarti tidak ada uang, pelampok/penghilang malu bisa digadai sebentar, barulah nanti ditembus), "rando dapek malu" (melahirkan tetapi tidak ada ayah atau malu mamak kemenakanya mau sekolah tinggi tapi uang tidak ada), dan "gadiah gadang ndak balaki (anak perempuan belum menikah)", namun penjualan tanah kaum di Alam Surambi Sungai Pagu jarang terjadi tanpa seizin ninik mamak.

Terkadang ada beberapa kasus di 5 nagari ini terjadi penjualan tanah kaum seperti di Nagari Pasir Talang Timur, salah satu keluarga yang mana orangtuanya sudah meninggal, sudara laki-laki mereka mengakaui tanah tersebut adalah miliknya. Namun saudara perempuan mereka tidak menyetujui akan hal itu dikarenakan tanah tersebut merupakan tanah kaum. Sehingga terjadi konflik antar kerluarga mereka.
Berkaitan dengan hal itu, jika terjadi penjualan tanah kaum tanpa seiizin ninik mamak, hal ini akan menimbulkan sebuah konflik tidak hanya dalam keluarga mereka tetapi juga di dalam suku. Namun penjualan tanah kaum di Alam Surambi Sungai Pagu jarang terjadi tanpa seizin ninik mamak.

d. mancancang malatiah atau maramba tanah kosong yang dilakukan oleh ninik mamak dulunya dan kemenakan untuk tujuan pengembangan ekonomi, mengenai tanah kaum sebenarnya tanah kaum dapat di diperluas dengan cara membuka ulayat suku yang belum diolah seperti rimbo yang belum di rambah ataupun tanah yang masih kosong. Hal ini menyebabkan tanah kaum dapat ditemuka di daearah bukaan lahan baru yaitu ulayat Adat Koto Baru dan Ulayat Adat Alam Pauh Duo, sehingga jika ditemukan di Nagari Pulakek Koto Baru memiliki tanah kaum di Simancung sepeti Bapak Dtk Ktk Lelo di Rajo yang memiliki tanah kaum di Simancung ataupun Suku Kampai yang ulayat kaumnya secara adat di Pakan Rabaa, namun kaum kampai juga memiliki tanah kaum di Pasir Talang Timur. Hal ini dikarenakan mamak dari mereka yang membuka ladang ataupun sawah di sana. Pembukaan lahan ini dikarenakan beberapa hal menurut Bapak Dtk St Mamat;

"...dek kareno kemenakan lah batambah, mangkonyo niniak mamak yang rajin tadi buka lahan baru di disnan mode Dtk Lelo di Rajo inyo bukak lahan di Simancung tu baguno untuk kemenakannyo beko (dikarenakan jumlah kemenakan bertambah, mangkanya niniak mamak yang rajin tadi buka lahan baru disana seperti bapak Dtk Lelo di Rajo dia buka lahan baru di Simancung itu nantinya berguna untuk kemenakanya)".

Mencancang malatiah atau maramba ulayat kaum baru ini biasanya pada daratan rendah yang belum di olah sama sekali. Hal

\section{2 | P a g e}

DOI: 10.25077/jantro.v20.n2.p191-211.2018

JANTRO ISSN: 2355-5963 (Online)

under Lisensi Creative Commons Atribusi-BerbagiSerupa 4.0 Internasional 
ini terjadi akibat lahan yang belum diolah pada suatu daerah seperti dataran rendah di bukit kandi atau pembukaan daearah admnistratif baru.

d) Tabek tabang atau meramba rimbo yang dilakukan oleh ninik mamak dan kemenakan untuk mengolah ulayat suku menjadi ulayat saprauik. Di Alam Surambi Sungai Pagu hutannya berada di bukit-bukit maka hutan juga disebut dengan bukik. Rimbo ini pada awalnya status kepemilikanya secara suku. Terkadang, ada beberapa orang yang sudah mengclaim rimbo tersebut milik pribadi akibat pembelian ataupun karena dia yang awal membuka rimbo tersebut.

“...Menurut Bapak Dtk Sutan Mamat, niniak mamak nyo tu rajin dulunyo mangkonyo di rimbo sinan ado ladang (niniak mamak mereka rajin dulunya dia sanggup sampai membuka lahan di bukit sana, makanya ada ladang mereka disana)".

d) Mengaku mamak, jika ada orang luar baik orang Solok, orang Sijunjung yang ingin mengolah lahan di Alam Surambi Sungai Pagu. Selain dengan cara menikah mereka dapat mengolah lahan disana dengan cara mengaku mamak. Hal ini dilakukan dengan cara mengaku sesama suku dan meminta izin dengan ninik mamak untuk mengolah tanah kaum. Begitu juga dengan orang Jawa yang kebanyakan bisa mengaku mamak dengan membeli suku, sehingga ia dapat mengolah tanah kaum tertentu atau mendapati suku. Jika orang Jawa ingin mengaku suku maka dia akan membeli suku tersebut dengan mandabiah kambing (memotong kambing), sehingga beberapa kasus di Pekan Rabaa, Pasir Talang, Koto Baru dan Pauh Duo sudah banyak terdapat orang luar yang mengolah ulayat kaum.
"mengaku mamak, disiko bemacam- macam ado di dalam nagari ko ado yang mangaku mamak ka suku kampai berarti kemenakan kami dan mbuek surat kawin, mengenai tanah di Koto Parik Gadang Diateh tentu

tiok kaum lah punyo haknyo apo ko bali atau punyo mamaknyo, ulayat suku ko tu ulayat kaum kemenakan perempuan yang punyo"

e. hasil pembelian dan upah buruh, selain mengaku mamak ada cara lain untuk dapat mengolah lahan di suku tertentu degan cara membeli tanah tersebut biasanya hal ini terjadi dikarenakan suku tersebut hanya membukanya saja seperti di Simancung yang kebanyakan setelah di ramba dan dijualnya kepada orang lain. Contoh lainnya seperti milik tanah kaum suku kampai di Pekan Rabaa milik Rajo Tuanku Bagindo yang mana sawah mereka banyak di kerjakan orang lain dengan bagi hasil. Dulunya juga banyak melakukan silih rugi tanah, silih rugi tanah ini pembelian bukan menggunakan uang dulunya. Tetapi menggunakan penukaran benda, sehingga banyak sekarang tanah yang didapatkan karena hasil silih rugi dulunya ${ }^{1}$.

"Menurut Bapak $P$ yang berasal dari ulu Suliti, awak bali dulu 3 juta, payah dulu masuak rimbo pakan salasa, kini jalan lah rancak, kalau nio bali dulu ado jorong diateh suraik, kalau yang iko punyo kaum keceknyo, ko punyo pribadi, jadi urang yang punyo sabalah ko harus tahu dan manakan suraik jual bali tanah, kadang jalan lah racak bantindaknyolai, kalau ado saksi tu ndak bisa, sabab disiko lah babuek surek pajanjian (saya dulu beli tanah ini 3 juta, dulu sangat sulit masuk hutan pakan salasa, sekarang sudah bagus jalan, kalau mau beli dulu harus ada jorong dan diatas surat, kita mesti tahu tanah ini milik kaum, yang ini milik pribadi, jadi orang yang punya sebelahan tanah harus juga tahu dan tanda tangan surat jual beli tanah, kadang jalan sudah bagus orangnya mau tanahnya kembali makanya kalau sudah ada saksi itu tidak bisa lagi, sebeb kalau

\footnotetext{
${ }^{1}$ Tetapi ada juga sekarang dengan membuat bukti sega yang mana dikeluarkan oleh KAN.
}

DOI: 10.25077/jantro.v20.n2.p191-211.2018

JANTRO ISSN: 2355-5963 (Online)

under Lisensi Creative Commons Atribusi-BerbagiSerupa 4.0 Internasional

203 | P a g e 
disini sudah ada perjanjian diatas surat)".

"Berdasarkan penjelasan lainnya lbu $B$, jikalau ada suku lain yang mempunyai ladang di ulayat kampai, padahal bukan ulayat suku dia di Koto Parik Gadang Dibawah berarti dia membeli lahan tersebut, dan penjualan tersebut hanya antar suku Alam Surambi Sungai Pagu, biang tabuik ganting putuih berarti memberi gelar seseorang walaupun dia bukan suku Parik Diateh"

f. Investor perusahaan kayu dan tambang, kelompok tani, dan koperasi merupakan skema pembukaan ulayat suku yang mana dapat dimanfaatkan oleh seseorang yang ingin melakukan penguasaan lahan untuk pengembangan ekonomi anak nagari. Hal ini terjadi akibat legalnya peraturan daerah tentang pengolahan hutan di ulayat adat. Beberapa investor berkat bantuan anak kemenakan yang mendapatkan izin dari rajo dan ninik mamak untuk mengolah wilayah adat. Sebagian perusahan itu berdiri merupakan usaha anak kemenakan dari masing-masing ulayat adat baik perusahan kayu dan tambang. Namun ada beberapa daerah yang perusahan tersebut didirikan secara ilegal. Dengan adanya perusahaan kayu, perkebunan dan tambang tersebut maka rajo dan ninik mamak akan mendapatkan keuntungan atau ganti rugi berupa uang dalam pembukaan wilayah suku tersebut.

\begin{abstract}
"Menurut Dtuak St M dan Dtk L Drjo, banyak anak kemenakan ko mangolah rimbo inyo tabang kayu sacaro ilegal, inyo tambang ameh, kalau ndak diagiah ndak ado karajo inyo daripado inyo ndak ado karajo dipadian se (banyak anak kemenakan ini mengolah hutan, kalau tidak diberi tidak ada kerjanya, lebih baik dibiarkan saja)"
\end{abstract}

Selain melalui investor, beberapa ulayat kaum di buka oleh kelompok tani dan koperasi. Beberapa kelompok tani dan koperasi dapat membuka ulayat adat dengan mengajukan kepada pemerintah Nagari, KAN dan izin ninik mamak di ulayat adat tersebut. Beberapa kasus di Pulakek Koto Baru, Pekan Rabaa, Alam Pauh Duo yang beberapa rimbo dibuka oleh kelompok tani dan koperasi. Nyatanya pada kelompok tani ataupun koperasi tersebut dibentuk dengan beberapa suku yang berbeda, bahkan suku yang bukan asli orang Alam Surambi Sungai Pagu, sehingga dapat dijumpai beberapa suku luar yang mengolah ulayat adat. Namun sejatinya dalam pengolahan ulayat suku dapat digunakan siapa saja baik orang luar atau pendatang, asalkan mendapatkan izin dengan rajo dan ninik mamak dan berdomisili di Alam Surambi Sungai Pagu.

\section{Antara Ulayat Adat dan Hutan Nagari}

$\mathrm{S}$ ejatinya produk hukum ini diciptakan merupakan salah satu cara melegalkan hutan pada masyarakat Minangkabau yang mana tidak ada sepeserpun hutan adat milik negara awalnya. Sehingga pemberian hak akses kepada masayarakat, tanpa disadari sejalan dengan memberikan perlindungan hutan dan memberikan hak perusahaanperusahan untuk mengolah hutan. Tanpa disadari juga kekuasaan orang-orang tertentu yang memiliki akses yang dapat mengolah hutan nagari sebagaimana yang telah dijelaskan oleh Ribot dan Peluso (2003:157) mengenai kemampuan untuk memperoleh manfaat dari suatu benda. Akses dalam pengertian Ribot dan Peluso ini berupa bundel atau sekumpulan kekuasaan (bundel of power) dan jaringjaring kuasa (web of power), dengan adanya produk hukum tersebut masyarakat khususnya masyarakat di Hutan Nagari terdapat sekumpulan orang dalam pengolahan hutan nagari. Nyatanya kekuasaan tersebut hanya dimiliki orangorang tertentu saja. Berkaitan dengan hal itu hak masyarakat adat dengan adanya produk hukum tidak menjamin bahwa seluruh masayarakat dapat mengolah hutan adat mereka, kemampuan aktor untuk mendapat menfaat sumber daya alam

\section{4 | P a g e}

DOI: 10.25077/jantro.v20.n2.p191-211.2018

JANTRO ISSN: 2355-5963 (Online)

under Lisensi Creative Commons Atribusi-BerbagiSerupa 4.0 Internasional 
ditentukan oleh faktor-faktor yang beragam, seperti akses terhadap teknologi, modal, pasar, pengetahuan, otoritas, identitas sosial, dan juga relasi sosial (lihat Darmanto dan Setyowati: 2012:20). Maka dari itu penelitian ini akan mengungkap pengertian ulayat adat masyarakat di 5 Hutan Nagari, dan dengan adanya SK Hutan Nagari apakah hal itu menguntungkan bagi seluruh masyarakat dalam mengolah wilayah adat mereka.

Semenjak kedatangan Belanda tidak banyak merombak kehidupan Masyarakat Alam Surambi Sungai Pagu. Kedatangan Belanda merubah fungsi hutan yang semulanya belum banyak diolah oleh masyarakat. Belanda mengakui adanya raja tetapi Belanda juga membentuk kepalo suku yang akhirnya mengaburkan kedudukan rajo. Kepalo suku diperintahkan untuk mengumpulkan upeti berupa sawah dan ladang milik masyarakat, sedangkan rimbo yang belum diolah dan curam dilarang untuk dilolah. Tetapi Belanda juga berhasil membuat perkebunan di dearah Pekonina dan Belanda lebih banyak menguasai wilayah perkebunan di dearah Kayu Aro. Semasa Belanda pengolahan hutan sudah mulai di lakukan di Alam Surambi Sungai Pagu, hanya saja pembukaan wilayah hutan hanya dilakukan secara pribadi guna kepentingan Belanda. Namun semenjak Belanda datang sudah terjadi pelarangan pengolahan hutan yang ketinggianya lebih dari $45^{\circ}$ di Alam Surambi Sungai Pagu. Sehingga banyak masyarakat tidak banyak mengolah hutan pada masa itu. Apalagi semasa Indonesia Merdeka pada era Soeharto, belum intensifnya pengolahan hutan di Alam Surambi Sungai Pagu, memberikan keuntungan pemerintah dengan diberlakukannya kebijakan mengenai perlindungan hutan. Produk hukum peninggalan Belanda yang menyamatarafkan hak atas tanah di Indonesia sesuai dengan UU Agraria No. 55 Tahun 1870. Hal itu juga berlaku semasa pemerintahan Indonesia yang mana pemerintah sebagai penguasa tanah beradasarkan lembaran Negera No. 94F Tahun 1874 yang berbunyi semua tanah yang belum dikerjakan atau tanah liar di Pulau Sumatera yang telah dijajah Belanda, selama dari hak penduduk hak-haknya yang dapat dari hukum pembukaan tanah, adalah mik negara. Atas tanah milik negara itu, hanya berlaku hakhak yang dipegang negara dengan mengingat hak rakyat guna membuka lahan. Sehingga hutan-hutan yang belum terdapat kepemilikan di Alam Surmabi Sungai Pagu menjadi milik negara. Produk hukum yang membatasi masyarakat tentang tanahnya tidak berhenti sampai disana dengan dikeluarkannya UU Pokok Agraria No. 5 Tahun 1960 dan UU lainnya yang mengatur beberapa jenis hak. Sehingga negara memberi patok-patok untuk menandai wilayah hutan sebagai hutan lindung dan hutan produksi bekas hutan lindung dari Belanda. Ladang masyarakat termasuk dalam kawasan hutan lindung yang tidak boleh diakses oleh masyarakat, sedangkan bagian barat bukit barisan dijadikan hutan produksi. Walaupun semenjak peraturanperaturan itu berlaku masyarakat tidak pernah menganggap hutan tersebut merupakan hutan negara, karena bagi mereka tidak ada sejengkalpun hutan milik negara yang hanya ada bahwa hutan merupakan milik 4 ulayat adat. Nyatanya sebagian masyarakat memang menyatakan bahwa hutan tersebut merupakan hutan lindung dari Belanda, sehingga setelah berlakunya pembagian wilayah batas-batas hutan oleh pemerintah mengaburkan status hutan dan masyarakat tanpa sadar mengakui bahwa hutan tersebut merupakan hutan lindung.

Tidak hanya itu, pemerintah juga membentuk wilayah admnistratif untuk pengolahan wilayah di Alam Surambi Sugai Pagu. Setidaknya sudah beberapa kali perubahan sistem pemeritah di wilayah Alam Surambi Sungai Pagu, pada tahun 1960 Alam Surambi Sungai Pagu resmi menjadi satu Kecataman dengan 2 Nagari yaitu Nagari Pasir Talang dan Nagari Koto Baru, dibawah nagari terdapat luhak dan kampung-kampuang dihimpun menjadi beberapa desa. Dengan adanya pemerintahan administratif memudahkan pemerintah untuk mengatur dan mengolah wilayah di Alam Surambi Sungai Pagu dengan dibentuknya Kepala Desa (Wali 
Nagari). Pada tahun 1999 kemudian dikeluarkanya peraturan baru 2000 dengan otonomi daerah, peraturan ini juga berimbas kepada daerah admnistratif di Alam Surambi Sungai Pagu yang pada masa itu masih tergabung daerah Kabupaten Solok, sehingga daerah luhak dan kampung berubah menjadi daerah adminstratif terendah yaitu jorong. Disusul dengan lepasnya Alam Surambi Sungai Pagu dengan Rantau XII Koto menjadi kabupaten tersendiri yaitu Kabupaten Solok Selatan terkhususnya Alam Surambi Sungai Pagu betambah menjadi 2 kecamatan pada tahun 2004 yaitu Kecamatan KPGD dengan Nagari Pekan Rabaa merupakan bekas balai atau pasar hari rabu dan Kecamatan Pauh dengan terdapat juga balai hari selasa atau Pekan Selasa yang menjadi Nagari Alam Pauh Duo. Pemberian batas administratif mengaburkan batas-batas ulayat yang pada akhirnya pengcalaiman hutan belum dirambah milik nagari dan jorong masing-masing. Semasa berubahnya daerah administratif penguasaan rajo mulai melemah, tidak adaya pergantian rajo sebagai penguasa dan pangatur 4 ulayat suku masing-masing di Alam Surambi Sungai Pagu. Sehingga rata-rata umur raja sudah tua, bahkan terkhusus raja Disambah telah meninggal, namun belum berujung pergantian. Perebutan antar garis keturunan yang ingin menjadi raja akhirnya pergantian raja sangat sulit di pilih kembali. Seiring dengan itu pembentukan KAN di 4 wilayah adat ini, memperjelas pengizinan secara administratif.

Pengolahan hutan di Alam Surambi Sungai Pagu menjadi tindakan ilegal pada semasa Soeharto, walaupun tindakan ilegal masih saja beberapa masyarakat berladang dilereng bukit. Pada tahun 1998 pemerintah memberikan izin perusahaan kayu dari Malaysia yang masuk di wilayah Alam Surambi Sungai Pagu tepatnya di wilayah Pekan Rabaa dan Pasir Talang untuk memanfaatkan hutan di Bukit Kandi, dimasa inilah pula maraknya penebangan kayu liar yang tejadi di tiap-tiap nagari dan masyarakat mulai menyadari mulai berharganya kayu sebagai mata pencaharian. Hal inilah yang menyebabkan hutan mulai diolah oleh anak kemenakan, karena mereka mengangap hutan merupakan ulayat adat yang boleh diolah oleh anak kemenakan, namun status hukum mereka kurang karena mereka melakukan tindakan ilegall logging. Dengan demikan banyak oknum-oknum yang bekerja sama, sehingga pelarangan yang dilakukan masyarakat baik ninik mamak terhadap hutan ulayat melemah. Hanya orang yang berkuasa saja, memiliki izin dan dekat dengan oknumoknum untuk mengolah rimbo di Alam Surambi Sungai Pagu. Sebelum maraknya penebangan liar, sudah ada beberapa masyarakat yang mengolah ladang di hutan lepas atau rimbo gadang, namun ladang tersebut merupakan ladang pribadi dengan beberapa skema baik membuka lahan untuk perkebunan di rimbo Pekan Rabaa, lahan yang dibuka secara bersama seperti koperasi atau kelompok tani di Simancung. Setelah berakhirnya masa Soeharto, tidak memberhentikan masyarakat untuk pemanfaatan hutan di Alam Surambi Sungai Pagu, apalagi setelah itu masuknya beberapa perusahaan tambang ilegall di beberapa hutan di Alam Surambi Sungai. Penghasilan ladang yang kurang membuat masyarakat mulai beralih mata pencaharian atau bekerja sebagai penambang ilegall, dan kelompok pengusaha yang sejatinya merupakan anak kemenakan yang memiliki jaringan degan orang luar mengerok keuntungan dengan adanya hasil bumi yang bisa di manfaatkan di Alam Surambi Sungai Pagu.

Setelah adanya peraturan megenai gencar-gencarnya reforma agraria untuk pengembalian pemanfaatan hutan sebagai hak milik masyarakat atau mengakui keberadaan akan adanya masyarakat adat. Sehingga beberapa produk hukum yang mulai dikeluarkan seperti Hutan Adat yang disahkan oleh Perda, atapun aturan yang mengatur tentang perhutanan sosial yang bertranformasi pada saat ini berdasarkan keputusan Permen LHK. No .83/2016. Perhutanan sosial ini terbagai menjadi beberapa skema yaitu Hutan Adat, Hutan Kemasyarakatan, Hutan Desa, Hutan Tanaman Rakyat, Hutan Kemitraan, dan IPHPS/KULIN KK. Produk hukum tersebut

\section{6 | P a g e}

DOI: 10.25077/jantro.v20.n2.p191-211.2018

JANTRO ISSN: 2355-5963 (Online)

under Lisensi Creative Commons Atribusi-BerbagiSerupa 4.0 Internasional 
menyamakan status hutan yang berada di tiap-tipa desa di Indonesia. Tanpa menilai status hutan bagi masyarakat adat itu sendiri. Sejatinya hal itu juga terjadi pada hutan di Alam Surambi Sungai Pagu berkat keberhasilan LSM Warsi dan pemerintah Sumbar pada tahun 2008 yang tujuannya untuk melindungi hutan dan memberikan hak pengolahan pada masayarakat Alam Surambi Sungai Pagu secara hukum pada Hutan Nagari di Simancung. Beberapa nagari mulai mengajukan hutan mereka menjadi hutan nagari yang semulanya merupakan ulayat suku yang pada dataran rendah sudah terbagi-bagi menjadi milik beberapa kaum, sedangkan status rimbo masih banyak yang belum diolah. Masyarakat terkendala dalam mengolah akibat status hutan yang menurut negara milik negara dan merupakan hutan lindung, walaupun secara adat merupakan ulayat adat.

Tabel 3. Antara Ulayat Adat dan Hutan Nagari

\begin{tabular}{|c|c|c|c|c|c|c|c|}
\hline No & $\begin{array}{c}\text { Nama } \\
\text { Hutan } \\
\text { Nagari } \\
\text { (admin.) }\end{array}$ & $\begin{array}{c}\text { Status } \\
\text { Kawa- } \\
\text { san }\end{array}$ & LPHN & $\begin{array}{c}\text { Ulayat } \\
\text { Adat }\end{array}$ & $\begin{array}{l}\text { Lokasi } \\
\text { Saat ini } \\
\text { (admin.) }\end{array}$ & $\begin{array}{c}\text { Nagari } \\
\text { administratif } \\
\text { lain yang } \\
\text { terkait }\end{array}$ & $\begin{array}{c}\text { Wilayah } \\
\text { kewena- } \\
\text { ngan KAN }\end{array}$ \\
\hline 1 & $\begin{array}{l}\text { Hutan } \\
\text { Nagari } \\
\text { Pakan } \\
\text { Rabaa } \\
\text { Luas: } \\
4.260 \text { ha }\end{array}$ & $\begin{array}{l}\text { HL dan } \\
\text { HPT }\end{array}$ & $\begin{array}{l}\text { 1. } \\
\text { Caniago, } \\
\text { 2. Kutu } \\
\text { anyia, } \\
\text { Sikumbang } \\
\text { (Tigo } \\
\text { Lareh) } \\
\text { 3. Kampai }\end{array}$ & $\begin{array}{l}\text { Ulayat adat } \\
\text { koto parik } \\
\text { gadang } \\
\text { diateh. } \\
\text { (ulayat } \\
\text { suku } \\
\text { kampai/Tu } \\
\text { anku Rajo } \\
\text { Bagindo) }\end{array}$ & $\begin{array}{l}\text { Kecamatan } \\
\text { Koto Parik } \\
\text { Gadang } \\
\text { Diateh }\end{array}$ & $\begin{array}{l}\text { i) Nagari } \\
\text { Pakan Rabaa } \\
\text { Timur; ii) } \\
\text { Nagari Pakan } \\
\text { Rabaa Barat; } \\
\text { iii) Nagari } \\
\text { Pakan Rabaa } \\
\text { Tengah; iv) } \\
\text { Nagari Pakan } \\
\text { Rabaa Induk } \\
\text { v) Pakan } \\
\text { Rabaa Utara }\end{array}$ & $\begin{array}{l}\text { KAN } \\
\text { Pakan } \\
\text { Rabaa } \\
\text { termasuk } 7 \\
\text { Penghulu } \\
\text { baru }\end{array}$ \\
\hline 2 & $\begin{array}{l}\text { Hutan } \\
\text { Nagari } \\
\text { Pasir } \\
\text { Palang } \\
\text { Timur } \\
\text { Luas : } \\
2.395 \mathrm{Ha}\end{array}$ & $\begin{array}{l}\text { HL dan } \\
\text { HPT }\end{array}$ & 1. & $\begin{array}{l}\text { Ulayat adat } \\
\text { Pasir } \\
\text { Talang } \\
\text { (Ulayat } \\
\text { Rajo Nan } \\
\text { batigo; } \\
\text { Suku } \\
\text { Malayu, } \\
\text { Tigo } \\
\text { Lareh, } \\
\text { Panai) }\end{array}$ & $\begin{array}{l}\text { Kecamatan } \\
\text { Sungai } \\
\text { Pagu }\end{array}$ & $\begin{array}{l}\text { Pasir Talang } \\
\text { Barat, Timur, } \\
\text { Tengah, Induk }\end{array}$ & $\begin{array}{l}\text { KAN Pasir } \\
\text { Talang }\end{array}$ \\
\hline 3 & $\begin{array}{l}\text { Hutan } \\
\text { Nagari } \\
\text { Koto Baru } \\
1.145 \mathrm{Ha}\end{array}$ & $\begin{array}{l}\text { HL dan } \\
\text { HPT }\end{array}$ & Pendatang & $\begin{array}{l}\text { Ulayat adat } \\
\text { koto baru } \\
\text { (Ulayat } \\
\text { Suku Rajo } \\
\text { Nan } \\
\text { Batigo; } \\
\text { Suku } \\
\text { Melayu, } \\
\text { Tigo } \\
\text { Lareh dan } \\
\text { Panai) }\end{array}$ & $\begin{array}{l}\text { Kecamatan } \\
\text { Sungai } \\
\text { Pagu }\end{array}$ & $\begin{array}{l}\text { Koto Baru, } \\
\text { Pulakek Koto } \\
\text { Baru, Pasar } \\
\text { Muaro Labuh } \\
\text { Koto Baru dan } \\
\text { Bomas Koto } \\
\text { Baru, Sako } \\
\text { Pasir Talang, } \\
\text { Sako Selatan } \\
\text { Pasir Talang }\end{array}$ & $\begin{array}{l}\text { KAN Koto } \\
\text { Baru }\end{array}$ \\
\hline
\end{tabular}


JURNAL ANTROPOLOGI: Isu-Isu Sosial Budaya. December 2018, Vol. 20 (2): 191-211 ISSN 1410-8356 Online at http://jurnalantropologi.fisip.unand.ac.id/index.php/jantro

\begin{tabular}{|c|c|c|c|c|c|c|c|c|}
\hline 4 & $\begin{array}{l}\text { Hutan } \\
\text { Nagari } \\
\text { Pulakek } \\
\text { Koto Baru } \\
\text { (4.265 ha) }\end{array}$ & $\begin{array}{l}\text { HL dan } \\
\text { HPT }\end{array}$ & $\begin{array}{l}\text { 1. Bariang } \\
\text { Melayu } \\
\text { Ampek } \\
\text { paruik } \\
\text { Koto } \\
\text { kaciak } \\
\text { Durian } \\
\text { (Suku } \\
\text { Melayu) }\end{array}$ & $\begin{array}{l}\text { Ulayat adat } \\
\text { koto baru } \\
\text { (Ulayat } \\
\text { Suku Rajo } \\
\text { Nan } \\
\text { Batigo; } \\
\text { Suku } \\
\text { Melayu, } \\
\text { Tigo } \\
\text { Lareh, dan } \\
\text { Panai) }\end{array}$ & $\begin{array}{l}\text { Kecamatan } \\
\text { Sungai } \\
\text { Pagu }\end{array}$ & $\begin{array}{l}\text { Koto Baru, } \\
\text { Pulakek Koto } \\
\text { Baru, Pasar } \\
\text { Muaro Labuh } \\
\text { Koto Baru dan } \\
\text { Bomas Koto } \\
\text { Baru, Sako } \\
\text { Pasir Talang, } \\
\text { Sako Selatan } \\
\text { Pasir Talang }\end{array}$ & $\begin{array}{l}\text { KAN } \\
\text { Baru }\end{array}$ & Koto \\
\hline 5 & $\begin{array}{l}\text { Hutan } \\
\text { Nagari } \\
\text { Alam Pauh } \\
\text { Duo (650 } \\
\text { ha) }\end{array}$ & $\begin{array}{l}\text { HL dan } \\
\text { HPT }\end{array}$ & $\begin{array}{l}\text { 1. Bariang, } \\
\text { Durian dan } \\
\text { Canigo } \\
\text { (Suku } \\
\text { Melayu } \\
2 . \\
\text { Pendatang }\end{array}$ & $\begin{array}{l}\text { Ulayat } \\
\text { Pauh Duo } \\
\text { (Ulayat } \\
\text { Suku Rajo } \\
\text { Nan } \\
\text { Batigo; } \\
\text { Suku } \\
\text { Melayu, } \\
\text { Tigo } \\
\text { Lareh dan } \\
\text { Panai) }\end{array}$ & $\begin{array}{l}\text { Kecamtan } \\
\text { Pauh Duo }\end{array}$ & $\begin{array}{l}\text { Nagari Alam } \\
\text { Pauh Duo, } \\
\text { Nagari Alam } \\
\text { Pauh Duo } \\
\text { Limo Tigo, } \\
\text { Nagari Kapau } \\
\text { Pauh Duo, } \\
\text { Nagari Luhak } \\
\text { Kapau Alam } \\
\text { Pauh Duo dan } \\
\text { Nagari } \\
\text { Pekonina } \\
\text { Alam Pauh } \\
\text { Duo }\end{array}$ & $\begin{array}{l}\text { KAN } \\
\text { Duo }\end{array}$ & Pauh \\
\hline
\end{tabular}

Semenjak dikeluarkanya pemberian SK. Hutan Nagari di 5 Hutan Nagari yaitu Hutan Nagari Simancung, Hutan Nagari Pekan Rabaa, Hutan Nagari Pasir Talang, Hutan Nagari Koto Baru dan Hutan Nagari Pulakek Koto Baru. Pemberian batas-batas yang selama ini berupa hutan lindung berubah menjadi 2 kawasan yaitu Hutan Lindung yang tidak boleh diolah dan Hutan Produksi Terbatas yang boleh diolah. Hal ini memberikan keuntungan masyarakat asli dan pendatang yang telah lama megolah hutan sebagai milik ladang mereka dalam kawasan Hutan Produksi, namun berbeda dengan masyarakat yang memiliki ladang yang sudah masuk Hutan Lindung. Tidak adanya aturan yang kuat dalam pelarangan di Hutan Lindung dan akhirnya masyarakat dibiarkan saja untuk mengolah. Ternyata pemberian legal masyarakat untuk mengolah hutan di dalam kawasan Hutan Nagari status HPT menguntungkan orangorang yang sudah miliki ladang dan tahu akan kebijakan Hutan Nagari. Adapun tidak banyak lagi kawasan HPT yang dapat dijadikan ladang, jikalaupun ada lokasi hutan tersebut sudah jauh dan masuk dalam kawasan HL.

Keuntungan juga didapatkan dari pengurus LPHN selaku Lembaga Pengolahan Hutan Nagari seperti LPHN Pasir Talang dan LPHN Pulakek Koto Baru, dengan skema hutan yang ada pada Hutan Nagari. LPHN Pasir Talang yang mana beberapa pengurusnya memiliki lahan ladang di Hutan Nagari, namun sejatinya mereka merupakan pendatang namun dikarenakan Hutan Nagari memberikan hak kepada seluruh masyarakat baik penduduk asli ataupun pendatang dapat mengolah Hutan Nagari. Begitu juga dengan pengurus LPHN Pulakek Koto Baru yang memanfaatkan skema Hutan Nagari di wilayah Hutan Produksi untuk mengolah hasil tambang biji emas yaitu PT. RAMB. Dengan adanya Hutan Nagari pemberian legal kepada LPHN dalam perlindungan hutan terhadap perusahan-perusahan yang ingin mengolah hasil kayu ataupun hasil bumi di Alam Surambi Sungai Pagu, berjalan lancar. Isu pemanfaatan eksploitasi hutan di Alam Surambi Sungai Pagu

\section{8 | P a g e}

DOI: 10.25077/jantro.v20.n2.p191-211.2018

JANTRO ISSN: 2355-5963 (Online)

under Lisensi Creative Commons Atribusi-BerbagiSerupa 4.0 Internasional 
berbanding terbalik dengan Hutan Nagari yang berada di Simancung, terkhusus hutan di Simancung merupakan kawasan Hutan Lindung yang memang di lindungi oleh masyarakat semenjak pembukaan lahan disana. Bahkan menjadi beberapa sorotan rapat 13 negara pada masa itu untuk melindungi hutan Simancung. Hanya saja penamaan hutan nagari yang tidak cocok karena lokasi hutan simancung berada di Jorong Simancung. Hal itu juga berbeda dengan Hutan Nagari di Koto Baru, pengurus LPHN yang bukan asli pendatang dan tidak memiliki ladang di Hutan Nagari Koto Baru. Menyebabkan kondisi hutan di Koto Baru tidak banyak diketahui.

Sejatinya ulayat suku digunakan untuk kepentingan bersama untuk kepentingan pengembangan ekonomi. Semenjak adanya pelegalan terhadap hutan menjadi Hutan Nagari masyarakat asli maupun pendatang memanfaatkan hutan untuk ladang secara pribadi. Adanya Hutan Nagari juga memberikan kewenangan kepada siapa saja yang ingin mengolah Hutan Nagari secara pribadi dengan skema perizinan. Semenjak tidak beroperasi lagi PT. AMT pada tahun 2012, pada tahun 2016 PEMDA mengeluarkan surat perizinan untuk pengolahan Bukit Kandi bekas PT.AMT untuk dikelola masyarakat, sebelum itu juga sudah banyak perusahan-perusahan yang meingicar bijih besi dan emas di Bukit Kandi. Dikarenakan adanya LPHN Pasir Talang dan LPHN Pekan Rabaa menggagalkan untuk pengolahan bukit kandi tersebut. Ternyata tidak seperti yang dibayangkan dibalik hal tersebut masyarakat pemilik modal sudah berlomba mengolah bekas PT. AMT tersebut untuk mengeruk hasil bumi di bukit kandi. Hal itu juga menjadi perebutan ulayat antara Pasir Talang dan Pekan Rabaa secara admnistratif dan mengaburkan ulayat adat antara Pasir Talang dan Pekan Rabaa.

\section{KESIMPULAN}

$\mathrm{K}$ ebijakan pemerintah mengeluarkan peraturan yang memberikan hak pengolahan hutan di Kabupaten Solok Selatan dengan skema Hutan Nagari tidak melihat secara langsung dalam pemanfaatan hutan di Alam Surambi Sunga Pagu. Bahwa secara kepemilikan merupakan ulayat adat terbagi menjadi 4 yaitu ulayat adat PGD, ulayat adat Pasir Talang, ulayat adat Koto Baru dan ulayat Pauh Duo. Ulayat adat ini terbagi menjadi rimbo yang merupakan hutan lepas yang memang belum diolah dan daratan rendah (tanah data). Ulayat adat ini digunakan untuk suku yang mana suku tersebut terbagi dalam beberapa kaum. Setiap anak kemenakan dalam kaum berhak memanfaatkan ulayat suku guna pengembangan ekonomi. Namun ketidaktahuan mekanisme masyarakat menegai hutan nagari dan lokasi hutan nagari yang ditetapkan berada di wilayah administaratif menyebabkan hanya daearah administratif saja yang dapat mengolah. Sedangkan realitanya pengolahan hutan nagari berupa ladang, pengolahan kayu dan tambang secara ilegal pada anak kemenakan ataupun pendatang yang sudah berdomisili di Alam Surambi Sungai Pagu, dengan adanya hutan nagari memberikan kemudahan kepada orang-orang tertentu saja dalam pengolahanya dan menjadi legal. Padahal ulayat adat ini tidak seperti yang dipikirkan oleh pemerintah, bahwa ulayat adat ini milik bersama ke 4 ulayat adat atau 4 ulayat suku yang kaum-kaumnya tinggal di satu kewilayahan yang sama dan dibatasi dengan kampuang-kampuang, sedangkan sekarang ini sudah terpisah secara administratif. Sehingga ditemukan batasbatas administratif yang tidak sesuai dengan ulayat adat, apalagi dengan pemekaran wilayah admnistratif seperti ulayat adat Parik Gadang Diateh merupakan miliki suku Kampai yang tinggal di seluruh Kecamatan Parik Gadang Diateh, ulayat adat Pasir Talang merupakan milik Suku Panai, Suku Tigo Lareh dan Suku Melayu yang tinggal di Nagari Pasir Talang, Nagari Pasir Talang Induak, Nagari Pasir Talang Timur dan sebagian wilayah luhak nan tujuah di wilayah KAN Koto Baru dan KAN Pauh Duo, sedangkan ulayat adat Koto Baru dan ulayat adat Pauh Duo merupakan ulayat perluasaan kekuasaan dari Pasir Talang dan penyebaran penduduk pendatang dan milik suku Panai, 
Suku Tigo Lareh dan Suku Melayu. Wilayah administaratif untuk ulayat adat Koto Baru yaitu Nagari Koto Baru, Pulakek Koto Baru, Pasar Muaro Labuh Koto Baru dan Bomas Koto Baru, Sako Pasir Talang, Sako Selatan Pasir Talang, sedankan wilayah administratif untuk ulayat adat Pauh Duo yaitu Nagari Alam Pauh Duo, Nagari Alam Pauh Duo Limo Tigo, Nagari Kapau Pauh Duo, Nagari Luhak Kapau Alam Pauh Duo dan Nagari Pekonina Alam Pauh Duo.

Adapun dari penjelasan diatas, peneliti merekomendasikan bahwa perlunya peraturan yang memang menjamin pelegalan penguasaan ulayat adat tidak hanya pada penunjukan dimana ulayat itu berada seperti penunjukan atau memberikan aturan Hutan Nagari di 5 Nagari yang mana Hutan Nagari tersebut berada di daerah administratif. Sebagaimana yang sudah dijelaskan seperti Hutan Nagari di Nagari Pekan Rabaa yang diolah masyarakat Nagari Pekan Raba, lalu bagaimana masyarakat Nagari lainnya yang masuk dalam ulayat adat dan tidak memiliki hutan begitu juga dengan Hutan Nagari lainnya. Walapun setelah ada penunjukan yang secara sah milik masyarakat berupa Hutan Nagari ataupun Hutan Adat yang dapat diolah seluruh masyarakat dalam ulayat adat, maka penting untuk pemerintah dan LSM mendampingi dalam pengolahan hutan tersebut. Dikarenakan pengolahan hutan tidak menyangkut hak kempilikan saja yang sudah diberikan secara adat tetapi terdapat juga aktor-aktor yang memainkan peran, memiliki kekuasaan, jaringan, uang untuk mengambil keuntungan dengan adanya pelegalan suatu hutan yang telah diakui negara terhadap Hutan Nagari atau Hutan Adat.

\section{E. UCAPAN TERIMAKASIH}

$\mathrm{P}$ enulis ingin mengucapkan trimakasih kepada KKI-Warsi yang telah memberikan bantuan dana dalam melakukan penelitian ini dan para tim tanah adat Minangkabau terkhusus untuk Bapak Yando yang telah mengarahkan dalam penulisan. Penulis juga tidak lupa mengucapkan trimakasih kepada masyarakat Alam Surambi Sungai Pagu, dengan adanya tulisan ini membuka pemikiran kita tentang keanekaragaman sistem tenurial masyarakat adat di Indonesia terkhususnya pada masyarakat Minangkabau. Sehingga perlulah pertimbangan para pemangku kebijakan untuk memberikan kewenangan dalam pengolahan sumber daya alam kepada masyarakat adat secara berkelanjutan dan tepat sasaran.

\section{DAFTAR PUSTAKA}

Adiwibowo, S. (2016). Materi untuk Kelompok Belajar Ekologi Politik.

Arifin dkk. (2005). Antropologi Ekologi. Laboratorium Antropologi FISIP.

Bogdan, Robert. (1992). Pengantar Metode Penelitian kualitatif : Suatu Pendekatan Fenomenologis Terhadap IImu-IImu Sosial. Surabaya: Usaha Nasional.

Damsar. (2001). Hak Atas Tanah Adat Minangkabau. Jurnal Antroplogi Universitas Andalas

Darmanto dan Setyowati. (2012). Berebut Hutan Siberu: Orang Mentawai, Kekuasaan dan Politik Ekologi. PT. Gramedia: Jakarta.

Erwin. (2005). Tanah Adat dan Agama Islam. Jurnal Antropologi Universitas Andalas

Erwin. (2012). Tanah Komunal Memudarnya Solidaritas Sosial pada Masyarakat Matrilinial Minangkabau. Andalas Univerisity Press.

KSPRI. (2017). Pelaksanaan Reforma Agraria. Strategi Reforma Agraria.

Ribot, J. C dan N. L. Peluso. (2003). A Theory of Access dalam Rural Sociological Society.68: 153-181.

Tresno. (2017). Ute' Simagere (Tengkorak Bagi Roh) : Relasi Masyarakat dengan Primata Endemik di Mentawai. Jurnal Antropologi: Isu-Isu Sosial Budaya. Juni 2017. Vol. 19 (1): $67-87$

\section{$210 \mid \mathrm{P}$ a g e}

DOI: 10.25077/jantro.v20.n2.p191-211.2018

JANTRO ISSN: 2355-5963 (Online)

under Lisensi Creative Commons Atribusi-BerbagiSerupa 4.0 Internasional 
JURNAL ANTROPOLOGI: Isu-Isu Sosial Budaya. December 2018, Vol. 20 (2): 191-211 ISSN 1410-8356 Online at http://jurnalantropologi.fisip.unand.ac.id/index.php/jantro

Poerwanto, Hari. (2006). Kebudayaan dan Lingkungan dalam Perspektif Antropologi. Pustaka Pelajar. Yogyakarta.

Suparlan, Parsudi. (2004). Hubungan Antar Suku Bangsa. Jakarta: YPKIK.

Zakaria dkk, (2018). Perhutanan Sosial: Dari Selogan Menajdi Program. Sekretariat Reforma Agraria dan Perhutanan Sosial.

Zakaria, R.Yando. (2017). Etnografi Tanah Adat Konsep-Konsep Dasar dan Pedoman Kajian Lapangan. Pusat Kajian Etnografi Hak-Hak Masyarakat Adat. 